\title{
Organ Specific Changes in Markers of Oxidative Stress in Choline, Carnitine and Caffeine Supplemented and Exercised Rats
}

\author{
Dileep S. Sachan*, Maike Johnsen, and Nobuko Hongu
}

Department of Nutrition, College of Education, Health and Human Sciences; and Agricultural Experiment Station, University of Tennessee, Knoxville, TN USA

Abstract: Objective: of this study was to determine changes in oxidative indices in tissues of exercised rats fed diet fortified with choline, carnitine and caffeine; and relate to those reported in humans.

Methods: 7-week old male Sprague-Dawley rats were studied for five weeks. Diets were supplemented with choline, carnitine and caffeine and rats were either exercised or not during the last 2 weeks of the dietary regimen. Tissue samples were collected at the end of the period and analyzed for the concentrations of TBARS, hydroperoxides and protein carbonyls.

Results: The changes modulated by the supplement as well as exercise regimens in the oxidative stress markers were tissue specific. The changes in serum TBARS of rats were unlike those in women under similar conditions of treatment we reported earlier.

Conclusions: The effects of choline, carnitine and caffeine supplements on the indices of oxidative stress were tissue specific and were not always correlated with serum TBARS. The changes in serum TBARS in rats were contrary to those reported in humans under similar conditions of treatment.

Keywords: Caffeine, carnitine, choline, exercise, oxidative-indices, TBARS, hydroperoxides, protein-carbonyls, rats.

\section{INTRODUCTION}

Mitochondrial machinery that oxidizes energy substrates and carries out respiration also produces significant amounts of reactive oxygen species (ROS), which leak out of mitochondria and cause substantial damage to various cellular components [1]. Thus enhanced mitochondrial activity is expected to enlarge the ROS pool and, in turn, contribute to oxidative stress [2]. Approximately $85-90 \%$ of oxygen we breathe is used by the mitochondria [3] and $2 \%$ of the total oxygen consumption in the resting state is used to produce $\mathrm{H}_{2} \mathrm{O}_{2}$ by the mitochondria [4]. Oxidative stress is the phenomenon of the imbalance of prooxidant and antioxidant elements in a living being. An increase in prooxidants or a reduction in antioxidants can shift the equilibrium towards prooxidants and thus enhance oxidative stress on the individual.

Carnitine and acylcarnitines have been suggested to improve mitochondrial function by reducing oxidants and prooxidants load [5-8]. Choline deficiency has been implicated in increasing prooxidants in tissue mitochondria [911]. There is some evidence that caffeine protects against radiation damage by decreasing TBARS, hydroperoxides and protein carbonyls and preserving levels of glutathione and superoxide dismutase [12]. However, combined effect of

*Address correspondence to this author at the 921 Parrish Road, Knoxville, TN 37923, USA; Tel: 865 690-0733; Fax: 865 690-0733;

E-mail: dsachan@utk.edu these dietary supplements on oxidative stress has not been studied outside our laboratory [13].

Earlier we have shown that choline promotes carnitine conservation in humans and animals and this conservation is reflected in accumulation of carnitine by all tissues especially the skeletal muscle $[14,15]$. A functional consequence of the increased carnitine was the loss of body fat in guinea pigs $[14,16]$. The addition of caffeine on top of choline and carnitine in the diets of rats resulted in reduction of regional fat pads and increased production of short-chain acylcarnitines which is indicative of enhanced fatty acid mobilization and oxidation $[17,18]$. Fatty acid oxidation is also known to be enhanced by Starvation and exercise besides dietary supplements [19]. Thus it was hypothesized that oxidative stress may be increased in choline, carnitine plus caffeine (CCC) supplemented rats. Our objective was to assess oxidative stress level in the male rats fed CCC-supplemented diets and exercised by determining the concentration of select markers of oxidative stress in their tissues.

\section{MATERIALS AND METHODS}

\section{Experimental Design and Treatment of Animals}

The study protocol was approved by the animal Care and Use Committee of University of Tennessee. Twenty 7-week old male Sprague-Dawley rats (Harlan Sprague-Dawley, Indianapolis, IN) were studied for four weeks. The rats were individually housed under conditions controlled for light (12-hour light-dark cycle), temperature $\left(20-22{ }^{\circ} \mathrm{C}\right)$ and rela- 
tive humidity (50\%). The rats were given free access to diet and water. The endogenous concentrations of choline and carnitine in the commercial diet, Teklad 22/5, were $2.1 \mathrm{~g}$ and $30 \mathrm{mg}$ per $\mathrm{kg}$ diet, respectively. The chow was nonsupplement (NS) diet. The supplemented (S) diet was commercial chow fortified with caffeine, carnitine, and choline at the rate of $0.1,5$ and $11.5 \mathrm{~g}$ per kg non-purified diet, respectively.

For the dietary treatment period of 4 weeks, the 20 rats were randomly divided into two groups and assigned to the $\mathrm{S}$ or NS diet $(n=10)$. During week 3-4, five rats of each dietary group were randomly assigned to exercise (E) routine and the other 5 rats were not exercised (NE). For exercise they were run on a rodent treadmill five days/week at $15 \%$ grade for $10 \mathrm{~min}$ at the start which was gradually increased to $18 \mathrm{~m} / \mathrm{min}$ for $25 \mathrm{~min} /$ day. The duration of diet and exercise treatment period was 4 and 2 weeks, respectively, and accordingly groups were designated as NS/NE, NS/E, S/NE and $S / E$. At the end of the 4th week, the rats were anesthetized and killed; blood samples were collected and immediately centrifuged at $2000 \mathrm{x}$ g for $10 \mathrm{~min}$. Following blood collection, liver, heart, kidney, skeletal muscle, testes and brain were excised from the carcasses, rinsed with saline solution, blotted dry and frozen in liquid nitrogen. Serum and tissues were stored at $-80{ }^{\circ} \mathrm{C}$ until analyzed for various metabolites.

\section{Reagents and Treatment of Samples}

Reagents were prepared and stored under controlled temperatures and in dark glass bottles. The samples stored at -80 ${ }^{\circ} \mathrm{C}$ were briefly thawed in water and placed in ice for complete thawing. Samples of one tissue type were always assayed in sets of minimum four (corresponding to each treatment) and repeated if a result of single determination appeared to be a complete outlier. Approximately $300 \mathrm{mg}$ frozen tissue samples were homogenized in $0.9 \%$ normal saline solution and centrifuged at low speed and resulting supernatant re-centrifuged at $10,000 \mathrm{x} \mathrm{g}$ at $4{ }^{\circ} \mathrm{C}$ for $10 \mathrm{~min}$. The final supernatant was collected into clean micro-centrifuge tubes with minimal air space and frozen at $-80{ }^{\circ} \mathrm{C}$ until assayed.

\section{Determination of Markers of Oxidative Stress}

The protein content of serum and tissue homogenates was determined by the method described by Bradford using a commercial dye reagent [20]. The lipid peroxide molecule, such as malondialdehyde (MDA) in serum and tissue homogenates were determined as thiobarbituric acid reactive substances (TBARS) with minor modifications, using the method originally described by Placer et al. [21] and modified by Ohkawa et al. [22]. The relationship between absorbance and concentrations was linear from 0.1 to 5 nmoles of MDA $(r=0.999)$. The FOX (ferrous ion oxidation with xylenol orange) assay, as described by Wolff [23], was used to determine water-soluble lipid hydroperoxides in serum and tissue homogenates. Absorbance and concentrations were linearly related from $0-5 \mu$ moles of hydrogenperoxide $(r=$ 0.997). Protein carbonyls in serum and tissue homogenates were determined according to the method described by
Levine and colleagues [24] and later modified by Reznick and Packer [25]. The principle of this assay involves the reaction of protein carbonyls with 2,4-dinitrophenylhydrazine to form protein hydrazones. The assay is sensitive to detect protein carbonyls in samples with $0.5 \mathrm{mg}$ per sample and results are reproducible with protein carbonyl contents of $0.2-1 \mathrm{mg}$ per $\mathrm{mg}$ proteins $(\mathrm{r}=0.999)$.

\section{Statistics}

All results are presented as group means \pm standard error of mean. Data were analyzed using two-way ANOVA. Duncan's post hoc test was applied for multiple comparisons. The correlations between concentrations of TBARS and lipid hydroperoxide or protein carbonyl were calculated. The statistical significance level was set at $\mathrm{p} \leq 0.05$.

\section{RESULTS}

The effects of exercise (NS/E), supplementation (S/NE) and the supplement cum exercise (S/E) compared to the control group i.e. without supplement and exercise (NS/NE) on TBARS, lipid hydroperoxides and protein carbonyls in serum, liver, muscle, brain, testis and kidney are presented in Tables 1 through 5.

\section{Serum}

The supplemented and exercised groups had significantly higher levels of TBARS $(\mathrm{p} \leq 0.01)$ compared to the NS/NE group (Table 1). Protein carbonyl concentrations were significantly higher in both supplemented groups ( $\mathrm{p} \leq 0.05)$, but not in the NS/E group. A significant interaction of supplement and exercise was observed for TBARS $(p \leq 0.01)$. TBARS and hydroperoxides were positively correlated, whereas TBARS and protein carbonyls were negatively correlated $(\mathrm{p} \leq 0.01)$.

\section{Liver}

The supplemented rats had significantly higher TBARS $(\mathrm{p} \leq 0.05)$ but had no significant change in protein carbonyl or hydroperoxide concentrations (Table 2). No significant change of TBARS concentration was observed with exercise alone. TBARS and protein carbonyls were positively correlated $(\mathrm{p} \leq 0.05)$.

\section{Skeletal Muscle}

Neither the TBARS nor hydroperoxide concentrations were affected by exercise or supplement (Table 3). However, exercise alone significantly lowered protein carbonyl concentrations when compared to those in the group with the supplement alone. A positive correlation was found between TBARS and hydroperoxides $(\mathrm{p} \leq 0.03)$

\section{Brain}

The data for TBARS and hydroperoxide concentrations did not differ significantly among the groups (Table 4). Protein carbonyl concentrations were decreased in both exercised groups but not in the group given the supplement alone $(\mathrm{p} \leq 0.01)$. A significant interaction of supplement and exercise was observed for protein carbonyls $(\mathrm{p} \leq 0.001)$. 
Table 1. Comparison of Serum TBARS, Hydroperoxide and Protein Carbonyl Concentrations in Rats Fed Diets With or Without Supplement and With or Without Exercise ${ }^{1}$

\begin{tabular}{|c|c|c|c|c|c|c|}
\hline \multirow[t]{2}{*}{ Groups } & \multicolumn{2}{|c|}{ TBARS } & \multicolumn{2}{|c|}{ Hydroperoxides } & \multicolumn{2}{|c|}{ Protein Carbonyls } \\
\hline & \multicolumn{6}{|c|}{ nmol/ mg Protein } \\
\hline $\mathrm{NS} / \mathrm{NE}$ & 0.09 & $\pm 0.01^{\mathrm{a}}$ & 0.54 & \pm 0.03 & 2.32 & $\pm 0.04^{\mathrm{a}}$ \\
\hline $\mathrm{NS} / \mathrm{E}$ & 0.20 & $\pm 0.02^{\mathrm{b}}$ & 0.39 & \pm 0.04 & 2.49 & $\pm 0.10^{\mathrm{ab}}$ \\
\hline $\mathrm{S} / \mathrm{E}$ & 0.23 & $\pm 0.02^{\mathrm{b}}$ & 0.42 & \pm 0.03 & 2.80 & $\pm 0.10^{\mathrm{b}}$ \\
\hline \multirow[t]{2}{*}{$\mathrm{S} / \mathrm{NE}$} & 0.23 & $\pm 0.01^{\mathrm{b}}$ & 0.40 & \pm 0.05 & 2.81 & $\pm 0.18^{\mathrm{b}}$ \\
\hline & \multicolumn{6}{|c|}{ Statistical significance ${ }^{2}$} \\
\hline Supplement & \multicolumn{2}{|c|}{$<0.001$} & \multicolumn{2}{|c|}{ NS } & \multicolumn{2}{|c|}{0.003} \\
\hline Exercise & \multicolumn{2}{|c|}{0.003} & \multicolumn{2}{|c|}{ NS } & \multicolumn{2}{|c|}{ NS } \\
\hline$S \times E^{3}$ & \multicolumn{2}{|c|}{0.004} & \multicolumn{2}{|c|}{ NS } & \multicolumn{2}{|c|}{ NS } \\
\hline
\end{tabular}

$\mathrm{NS}=$ no supplement, $\mathrm{S}=$ supplement, $\mathrm{NE}=$ no exercise, $\mathrm{E}=$ exercise

${ }^{1}$ Values are means \pm SEM $(n=5)$ and those bearing different superscript letters within a column are significantly different at $\mathrm{p} \leq 0.05$

${ }^{2}$ Two-way ANOVA, $\mathrm{p} \leq 0.05 ; \mathrm{NS}=$ not significant $(\mathrm{p}>0.05)$

${ }^{3}$ Supplement and exercise interaction

Table 2. Comparison of Hepatic TBARS, Hydroperoxide and Protein Carbonyl Concentrations in Rats Fed Diets With or Without Supplement and With or Without Exercise ${ }^{1}$

\begin{tabular}{|c|c|c|c|c|c|c|}
\hline & \multicolumn{2}{|c|}{ TBARS } & \multicolumn{2}{|c|}{ Hydroperoxides } & \multicolumn{2}{|c|}{ Protein Carbonyls } \\
\hline & \multicolumn{6}{|c|}{ nmol/mg Protein } \\
\hline $\mathrm{NS} / \mathrm{NE}$ & 0.42 & $\pm 0.01^{\mathrm{a}}$ & 3.55 & \pm 0.11 & 5.33 & \pm 0.24 \\
\hline $\mathrm{NS} / \mathrm{E}$ & 0.40 & $\pm 0.04^{\mathrm{a}}$ & 3.84 & \pm 0.05 & 5.26 & \pm 0.16 \\
\hline $\mathrm{S} / \mathrm{E}$ & 0.57 & $\pm 0.03^{\mathrm{b}}$ & 3.57 & \pm 0.13 & 5.93 & \pm 0.20 \\
\hline \multirow[t]{2}{*}{$\mathrm{S} / \mathrm{NE}$} & 0.49 & $\pm 0.03^{\mathrm{b}}$ & 3.31 & \pm 0.20 & 5.41 & \pm 0.29 \\
\hline & \multicolumn{6}{|c|}{ Statistical significance ${ }^{2}$} \\
\hline Supplement & \multicolumn{2}{|c|}{$<0.001$} & \multicolumn{2}{|c|}{ NS } & \multicolumn{2}{|c|}{ NS } \\
\hline Exercise & \multicolumn{2}{|c|}{ NS } & \multicolumn{2}{|c|}{ NS } & \multicolumn{2}{|c|}{ NS } \\
\hline$S \times E^{3}$ & \multicolumn{2}{|c|}{ NS } & \multicolumn{2}{|c|}{ NS } & \multicolumn{2}{|c|}{ NS } \\
\hline
\end{tabular}

$\mathrm{NS}=$ no supplement, $\mathrm{S}=$ supplement, $\mathrm{NE}=$ no exercise, $\mathrm{E}=$ exercise

${ }^{1}$ Values are means \pm SEM $(n=5)$ and those bearing different superscript letters within a column are significantly different at $\mathrm{p} \leq 0.05$

${ }^{2}$ Two-way ANOVA, $\mathrm{p} \leq 0.05$; NS $=$ not significant $(\mathrm{p}>0.05)$

${ }^{3}$ Supplement and exercise interaction

\section{Testes}

The supplementation had no effect on the TBARS concentration (Table 5). However, exercise alone significantly lowered TBARS concentration $(\mathrm{p} \leq 0.01)$. Hydroperoxides and protein carbonyl concentrations were not affected by exercise and/or supplement.

\section{Kidney}

No significant effect of any of the treatments was observed on any of the three markers of oxidative stress in this tissue (data not shown).

\section{DISCUSSION}

Since the combination of choline, carnitine and caffeine with or without exercise promotes fat mobilization and oxidation, it was hypothesized that these conditions may tip the balance in favor of oxidative stress $[17,18]$. However, in our study in women CCC supplementation reduced oxidation stress on the basis of TBARS measured in serum [13]. So it was logical for us to ask if the combination of CCC mitigated oxidative stress in many other organs of the body and for that we turned to rat model. Unfortunately, like in most studies samples were deep frozen before analysis could be performed which may have affected absolute values [26, 27] 
Table 3. Comparison of Skeletal Muscle TBARS, Hydroperoxide and Protein Carbonyl Concentrations in Rats Fed Diets with or without Supplement and With or Without Exercise ${ }^{1}$

\begin{tabular}{|c|c|c|c|c|c|c|}
\hline & \multicolumn{2}{|c|}{ TBARS } & \multicolumn{2}{|c|}{ Hydroperoxides } & \multicolumn{2}{|c|}{ Protein carbonyls } \\
\hline & \multicolumn{6}{|c|}{ nmol/mg protein } \\
\hline $\mathrm{NS} / \mathrm{NE}$ & 2.52 & \pm 0.26 & 1.05 & \pm 0.11 & 8.89 & $\pm 0.27^{\mathrm{ab}}$ \\
\hline $\mathrm{NS} / \mathrm{E}$ & 2.01 & \pm 0.14 & 0.94 & \pm 0.07 & 7.97 & $\pm 0.13^{\mathrm{a}}$ \\
\hline $\mathrm{S} / \mathrm{E}$ & 2.49 & \pm 0.35 & 1.30 & \pm 0.25 & 8.11 & $\pm 0.28^{\mathrm{ab}}$ \\
\hline \multirow[t]{2}{*}{$\mathrm{S} / \mathrm{NE}$} & 2.64 & \pm 0.54 & 0.89 & \pm 0.05 & 9.15 & $\pm 0.56^{\mathrm{b}}$ \\
\hline & \multicolumn{6}{|c|}{ Statistical significance ${ }^{2}$} \\
\hline Supplement & \multirow{2}{*}{\multicolumn{2}{|c|}{$\begin{array}{l}\text { NS } \\
\text { NS }\end{array}$}} & \multicolumn{2}{|c|}{ NS } & \multicolumn{2}{|c|}{ NS } \\
\hline Exercise & & & \multicolumn{2}{|c|}{ NS } & \multicolumn{2}{|c|}{0.012} \\
\hline$S \times E^{3}$ & \multicolumn{2}{|c|}{ NS } & \multicolumn{2}{|c|}{ NS } & \multicolumn{2}{|c|}{ NS } \\
\hline
\end{tabular}

$\mathrm{NS}=$ no supplement, $\mathrm{S}=$ supplement, $\mathrm{NE}=$ no exercise, $\mathrm{E}=$ exercise

${ }^{1}$ Values are means $\pm \operatorname{SEM}(\mathrm{n}=5)$ and those bearing different superscript letters within a column are significantly different at $\mathrm{p} \leq 0.05$

${ }^{2}$ Two-way ANOVA, $\mathrm{p} \leq 0.05 ; \mathrm{NS}=$ not significant $(\mathrm{p}>0.05)$

${ }^{3}$ Supplement and exercise interaction

Table 4. Comparison of Brain TBARS, Hydroperoxide and Protein Carbonyl Concentrations in Rats Fed Diets With or Without Supplement and with or Without Exercise ${ }^{1}$

\begin{tabular}{|c|c|c|c|c|c|c|}
\hline & \multicolumn{2}{|c|}{ TBARS } & \multicolumn{2}{|c|}{ Hydroperoxides } & \multicolumn{2}{|c|}{ Protein Carbonyls } \\
\hline & \multicolumn{6}{|c|}{ nmol/ mg Protein } \\
\hline $\mathrm{NS} / \mathrm{NE}$ & 2.31 & \pm 0.20 & 5.52 & \pm 0.24 & 9.87 & $\pm 0.50^{\mathrm{b}}$ \\
\hline $\mathrm{NS} / \mathrm{E}$ & 2.27 & \pm 0.06 & 5.56 & \pm 0.52 & 7.91 & $\pm 0.48^{\mathrm{a}}$ \\
\hline $\mathrm{S} / \mathrm{E}$ & 2.38 & \pm 0.17 & 5.88 & \pm 0.30 & 8.06 & $\pm 0.17^{\mathrm{a}}$ \\
\hline \multirow[t]{2}{*}{$\mathrm{S} / \mathrm{NS}$} & 2.55 & \pm 0.20 & 4.91 & \pm 0.56 & 10.83 & $\pm 0.52^{\mathrm{b}}$ \\
\hline & \multicolumn{6}{|c|}{ Statistical significance $^{2}$} \\
\hline Supplement & \multirow{2}{*}{\multicolumn{2}{|c|}{$\begin{array}{l}\text { NS } \\
\text { NS }\end{array}$}} & \multicolumn{2}{|c|}{ NS } & \multicolumn{2}{|c|}{ NS } \\
\hline Exercise & & & \multicolumn{2}{|c|}{ NS } & \multicolumn{2}{|c|}{$<0.001$} \\
\hline$S \times E^{3}$ & \multicolumn{2}{|c|}{ NS } & \multicolumn{2}{|c|}{ NS } & \multicolumn{2}{|c|}{0.001} \\
\hline
\end{tabular}

$\mathrm{NS}=$ no supplement, $\mathrm{S}=$ supplement, $\mathrm{NE}=$ no exercise, $\mathrm{E}=$ exercise

${ }^{1}$ Values are means $\pm \operatorname{SEM}(\mathrm{n}=5)$ and those bearing different superscript letters within a column are significantly different at $\mathrm{p} \leq 0.05$

${ }^{2}$ Two-way ANOVA, $\mathrm{p} \leq 0.05 ; \mathrm{NS}=$ not significant $(\mathrm{p}>0.05)$

${ }^{3}$ Supplement and exercise interaction

but not relative values of our experimental results as the parameters across the treatments were determined under identical conditions [28].

The increases in serum concentrations of TBARS and protein carbonyls, even without changes in lipid hydroperoxides, suggest higher degree of oxidative stress in the supplemented animals. Lipid hydroperoxides are not very stable and get transformed into more stable products such as alkanes and aldehydes, a form of the latter is MDA which is measured as TBARS [29] but these are not the artifacts of the TBA assay system itself [30]. Exercise independently affected serum TBARS in the manner similar to that caused by the supplements (Table 1). The increase in the concentrations of TBARS is also observed in liver and testes but not in skeletal muscle, brain and kidneys of the supplemented rats. Thus oxidative stress assessed through serum TBARS was not uniformly applicable to other tissues of the rats. Tissues have been shown to respond differently to oxidative stress and the markers may vary accordingly [31]. Further, the serum TBARS response to CCC supplementation in rat model was contrary to that we found in free-living women who showed significant reduction in concentration of serum TBARS after 1-2 weeks of supplementation [13]. Unlike the rats in the current study, caffeine was not a part of the supplement mix given to the women in our earlier study, however, they did consume on an average $240 \mathrm{mg}$ of caffeine per day from a variety of foods and beverages. The difference in response to choline and carnitine in humans vs rodents must 
Table 5. Comparison of Testes TBARS, Hydroperoxide and Protein Carbonyl Concentrations in Rats Fed Diets With or Without Supplement and With or Without Exercise ${ }^{1}$

\begin{tabular}{|c|c|c|c|c|c|c|}
\hline & \multicolumn{2}{|c|}{ TBARS } & \multicolumn{2}{|c|}{ Hydroperoxides } & \multicolumn{2}{|c|}{ Protein carbonyls } \\
\hline & \multicolumn{6}{|c|}{ nmol/ mg protein } \\
\hline $\mathrm{NS} / \mathrm{NE}$ & 0.50 & $\pm 0.09^{\mathrm{b}}$ & 7.95 & \pm 0.38 & 7.17 & \pm 0.77 \\
\hline $\mathrm{NS} / \mathrm{E}$ & 0.28 & $\pm 0.02^{\mathrm{a}}$ & 9.14 & \pm 0.46 & 7.13 & \pm 0.31 \\
\hline $\mathrm{S} / \mathrm{E}$ & 0.61 & $\pm 0.08^{\mathrm{b}}$ & 8.33 & \pm 0.59 & 8.10 & \pm 0.44 \\
\hline \multirow[t]{2}{*}{$\mathrm{S} / \mathrm{NE}$} & 0.64 & $\pm 0.02^{\mathrm{b}}$ & 8.83 & \pm 0.14 & 8.17 & \pm 0.32 \\
\hline & \multicolumn{6}{|c|}{ Statistical significance $^{2}$} \\
\hline Supplement & \multicolumn{2}{|c|}{0.001} & \multicolumn{2}{|r|}{ NS } & \multicolumn{2}{|r|}{ NS } \\
\hline Exercise & \multicolumn{2}{|c|}{ NS } & \multicolumn{2}{|r|}{ NS } & \multicolumn{2}{|r|}{ NS } \\
\hline$S \times E^{3}$ & \multicolumn{2}{|c|}{ NS } & \multicolumn{2}{|r|}{ NS } & \multicolumn{2}{|r|}{ NS } \\
\hline
\end{tabular}

$\mathrm{NS}=$ no supplement, $\mathrm{S}=$ supplement, $\mathrm{NE}=$ no exercise, $\mathrm{E}=$ exercise

${ }^{1}$ Values are means \pm SEM $(n=5)$ and those bearing different superscript letters within a column are significantly different at $\mathrm{p} \leq 0.05$

${ }^{2}$ Two-way ANOVA, $\mathrm{p} \leq 0.05 ; \mathrm{NS}=$ not significant $(\mathrm{p}>0.05)$

${ }^{3}$ Supplement and exercise interaction

be attributed to the species specific differences in metabolism e.g. rats metabolize choline 60 times faster than do humans [32].

In skeletal muscle TBARS and hydroperoxides were not affected by treatments. Contrary to the expectations that exercise may have enhanced oxidative stress in skeletal muscles, it actually mitigated any effect as evident from carbonyls data (Table 3). This may be related to the training, duration and intensity of exerciser regimen. Regular exercise has been shown to enhance concentrations of antioxidants in skeletal muscle and liver [33, 34]. Exercise has been shown to lower concentration of oxidized DNA in skeletal muscle without affecting TBARS and protein carbonyls [35]. These studies may indicate that oxidative stress induces antioxidant systems to cope with ROS [36].

The increase in TBARS concentration in liver of our rats is consistent with the increase of fatty acid oxidation in liver indicated by a rise of serum $\beta$-hydroxybutyrate [18] however, the antioxidative benefit of the supplement was not evident [13]. Perhaps the enhancement of mitochondrial activity under the influence of CCC far exceeded the antioxidation protection the levels of carnitine supplement could offer. Carnitine supplement alone has been shown to significantly improve antioxidation status in old but not in young rats [8, $37,38]$. The protection against peroxidation by carnitine may be related to conservation of tocopherol $[8,13,38,39]$ which in turn stabilizes membranes $[6,7]$.

It is concluded that effects of supplements and exercise on the indices of oxidative stress were tissue specific and they were not always correlated with serum TBARS. The changes in serum TBARS in rats were contrary to those seen in humans under similar conditions of treatment. This suggests species differences in metabolism and the diversity of tissue response within a species which deserves due consideration.

\section{CONFLICT OF INTEREST}

The authors confirm that this article content has no conflicts of interest.

\section{ACKNOWLEDGEMENTS}

The authors acknowledge the funding from AES of TN.

\section{REFERENCES}

[1] Beckman KB, Ames B. The free radical theory of aging matures. Physiol Rev 1998; 78: 547-81.

[2] Noguchi N, Niki E. Chemistry of active oxygen species and antioxidants. In: Papas AM. Ed: Antioxidant status, diet, nutrition, and health Bocca Raton: CRC Press. 1999; pp. 3-20.

[3] Gutteridge JMC, Halliwell B. Antioxidants in nutrition, health, and disease. Newyork: Oxford University Press 1994; p. 143.

[4] Clarkson PM, Thompson HS. Antioxidants: What role do they play in physical activity and health. Am J Clin Nutr 2000; 72: 637S46S.

[5] Packer L, Valenza M, Serbinova E, Starke-Reed P, Frost K, Kagan $\mathrm{V}$. Free radical scavenging is involved in the protective effect of Lpropionylcarnitine against ischemia-reperfusion injury of the heart. Arch Biochem Biophys 1991; 288 (2): 533-7.

[6] Palmieri L, Ronca F, Malengo S, Bertelli A. Protection of $\beta$ thalassaemicerythrocytes from oxidative stress by propionyl carnitine. Int J Tissue React 1994; XVI(3): 121-9.

[7] Ronca F, Palmieri L, Malengo S, Bertelli A. Effect of L-propionyl carnitine on in-vitro membrane alteration of sickle-cell anaemia erythrocytes. Int J Tiss Reac 1994; XVI (4): 187-94.

[8] Kalaiselvi T, Panneerselvam C. Effect of L-carnitine on the status of lipidperoxidation and antioxidants in aging rats. J Nutr Biochem 1998; 9: 575-81.

[9] Nakae D, Yoshiji H, Marujama H, Kinugasa T, Denda A, Konishi Y. Production of both 8-hydroxydeoxyguanosine in liver DNA and $\gamma$-glutamyltransferase-positive hepatocellular lesions in rats given a choline deficient, L-amino acid-defined diet. Jpn J Cancer Res 1990; 81: 1081-4.

[10] Hensley K, Kotake Y, Sang H, et al. Dietary choline restriction causes complex I dysfunction and increased $\mathrm{H}_{2} \mathrm{O}_{2}$ generation in liver mitochondria. Carcinogenesis 2000; 21 (5): 983-9.

[11] Zeisel SH, Blusztajn JK. Choline and human nutrition. Annu Rev Nutr 1994; 14: 269-96.

[12] Kamat JP, Boloor KK, Devasagayam TPA, Jayashree B, Kesavan PC. Differential modification by caffeine of oxygen-dependent and 
independent effects of $\gamma$-irradiation on rat liver mitochondria. Int. J Radiat Biol 2000;76 (9): 1281-8.

[13] Sachan DS, Hongu N, Johnsen M. Decreasing oxidative stress with choline and carnitine in women. J Am Coll Nutr 2005; 24: 172-6.

[14] Daily JW, Sachan DS. Choline supplementation alters carnitine homeostasis in humans and guinea pigs. J Nutr 1995;125: 1938-44.

[15] Dodson WL, Sachan DS. Choline supplementation reduces urinary carnitine excretion in humans. Am J Clin Nutr 1996; 63: 904-10.

[16] Daily JW, Hongu N, Mynatt RL, Sachan DS. Choline supplementation increases tissue concentrations of carnitine and lowers body fat in guinea pigs. J Nutr Biochem 1998; 9: 464-70.

[17] Hongu N, Sachan DS. Caffeine, carnitine and choline supplementation of rats decreases body fat and serum leptin concentration as does exercise. J Nutr 2000; 130: 152-7.

[18] Sachan DS, Hongu N. Increases in $\mathrm{VO}_{2}$ max and metabolic markers of fat oxidation by caffeine, carnitine, and choline supplementation in rats. J Nutr Biochem 2000; 11: 521-6.

[19] Papas AM. Determinants of antioxidant status in humans. In: Papas AM Ed: Antioxidant status, diet, nutrition, and health. USA: CRC Press 1999; pp. 21-36.

[20] Bradford MM. A rapid and sensitive method for the quantitation of microgram quantities of protein utilizing the principle of proteindye binding. Anal Biochem 1976; 72: 248-54.

[21] Placer ZA, Cushman LL, Johnson BC. Estimation of product lipidperoxidation (malonyl-dialdehyde) in biochemical systems. Anal Biochem 1966; 16: 356-64.

[22] Ohkawa H, Ohishi N, Yagi K. Assay for lipid peroxides in animal tissues by thiobarbituric acid reaction. Anal Biochem 1979; 95: 351-8.

[23] Wolff SP. Ferrous ion oxidation in presence of ferric ion indicator xylenolorange for measurement of hydroperoxides. Methods in Enzymol 1994; 233: 182-9.

[24] Levine RL, Williams JA, Stadtman ER, Shacter E. Carbonyl assays for determination of oxidatively modified proteins. Meth Enzymol 1994; 233: 346-57.

[25] Reznick AZ, Packer L. Oxidative damage to proteins: spectrophotometric method for carbonyl assay. Meth Enzymol 1994; 233: 357-63.

[26] Anderson ME. Determination of glutathione and glutathione disulfide in biological samples. Meth Enzymol 1985; 113: 548-555.
[27] Carlberg I, Mannervik B. Glutathione reductase. Meth Enzymol $1985 ; 113: 484490$.

[28] Reznick AZ, Witt E, Matsumoto M, Packer L. Vitamin E inhibits proteinoxidation in skeletal muscle of resting and exercised rats Biochem Biophys Res Commun 1992; 189(2): 801-6.

[29] Moore K, Roberts LJ. Measurement of lipid peroxidation. Free Rad Res 1998; 28: 659-671.

[30] Jiang Z-Y, Woollard ACS, Wolff SP. Lipid hydroperoxide measurement by oxidation of $\mathrm{Fe}^{2+}$ in the presence of xylenol orange. Comparison with the TBA assay and an iodometric method. Lipids 1991; 26 (10): 853-6.

[31] Jenkins RR. Exercise and oxidative stress methodology: a critique. Am J Clin Nutr 2000; 72 (Suppl. 2): 670S-4.

[32] Sidranski H, Farber E. Liver choline oxidase activity in man and several species of animals. Arch Biochem Biophys 1960; 87: 12933.

[33] Oh-Ishi S, Kizaki T, Ookawara T, et al. Endurance training improves the resistance of rat diaphragm to exercise induced oxidative stress. Am J Respir Crit Care Med 1997; 156: 1579-85.

[34] Quiles JL, Huertas JR, Manas M, Battino M, Ochoa JJ, Mataix J. Plasma antioxidants are strongly affected by iron-induced lipid peroxidation rats subjected to physical exercise and different dietary fats. Biofactors 1998; 8: 119-27.

[35] Radák Z, Kaneko T, Tahara S, et al. The effect of exercise training on oxidative damage of lipids, proteins, and DNA in rat skeletal muscle: evidence for beneficial outcomes. Free Radic Biol Med 1999; 27(1/2): 69-74.

[36] Pilger A, Germadnik D, Formanek D, Zwick H, Winkler N, Rüdiger HW. Habitual long distance running does not enhance urinary excretion of 8-hydroxydeoxyguanosine. Eur J Physiol 1997; 75: 467-9.

[37] Haripriya D, Sangeetha P, Kanchana A, Balu M, Panneerselvam C. Modulation of age-associated oxidative damage in rat brain cerebral cortex, striatum and hippocampus by 1-carnitine. Exp Gerontol 2005; 40: 129-35.

[38] Kumaran S, Deepak B, Naveen B, Panneerselvam C. Effects of levocarnitine on mitochondrial antioxidant systems and oxidative stress in aged rats. Drugs R D 2003; 4(3): 141-7.

[39] Zou W, Noh SK, Owen KQ, Koo SI. Dietary L-carnitine enhances the lymphatic absorption of fat and $\alpha$-tocopherol in overiectomized rats. J Nutr 2005; 135: 753-6.

(C) Sachan et al.; Licensee Bentham Open

This is an open access article licensed under the terms of the Creative Commons Attribution Non-Commercial License (http://creativecommons.org/licenses/by-nc/3.0/) which permits unrestricted, non-commercial use, distribution and reproduction in any medium, provided the work is properly cited. 